\title{
Capitals and Capabilities: A Framework for Analyzing Peasant Viability, Rural Livelihoods and Poverty
}

\author{
ANTHONY BEBBINGTON * \\ University of Colorado at Boulder, Boulder, USA
}

\begin{abstract}
Summary. - On the basis of themes emerging in current debates on rural development in Latin America, this paper develops an analytical framework for analyzing rural livelihoods in terms of their sustainability and their implications for rural poverty. The framework argues that our analyses of rural livelihoods need to understand them in terms of: (a) people's access to five types of capital asset; (b) the ways in which they combine and transform those assets in the building of livelihoods that as far as possible meet their material and their experiential needs; (c) the ways in which people are able to expand their asset bases through engaging with other actors through relationships governed by the logics of the state, market and civil society; and (d) the ways in which they are able to deploy and enhance their capabilities both to make living more meaningful and to change the dominant rules and relationships governing the ways in which resources are controlled, distributed and transformed in society. Particular attention is paid to the importance of social capital as an asset through which people are able to widen their access to resources and other actors. (C) 1999 Elsevier Science Ltd. All rights reserved.
\end{abstract}

Key words - sustainable livelihoods, assets, social capital, peasants, Latin America, Andes

\section{INTRODUCTION}

This paper is a response to the disappointing effects of development interventions in the high Andes and other such "marginal" environments (Zoomers, 1998; van Niekerk, 1997). It is not, though, an inquiry into why those impacts have been so limited; it is instead an effort to develop a framework that broadens our conception of rural livelihoods in such a way that may help rethink the nature, location and content of interventions so that they are more consonant with the diverse ways in which people make a living and build their worlds. As Zoomers (1998) has recently suggested for the Andes, and as Scott (1998) has argued more generally, one important reason projects fail is probably that they simply misperceive the way people get by and get things done. In particular, I want to suggest that a large part of the problem is that interventions work with ways of seeing the world that continue to crunch rural livelihoods into the category of agricultural and natural resource-based strategies. Even sophisticated frameworks aiming to analyze rural resource use emphasize access to environmental resources and ultimately convey an image of rural people making their living from natural resources (Leach, Mearns and Scoones, 1998, p. 7).

\footnotetext{
*I am grateful to the financial support from the Sustainable Agriculture and Rural Livelihoods Program at the International Institute for Environment and Development, and particularly to Simon Croxton who encouraged me to write this paper. Its preparation was partly funded by the UK Department for International Development's support to IIED's "Policies that Work for Sustainable Agriculture and Regenerating Rural Economies" research project, and by a Hewlett Fellowship at the Center for Advanced Study in the Behavioral Sciences at Stanford (1998-99) which provided a great environment to round out the thinking the paper aims to crystallize. Comments from Simon Croxton, Neela Mukherjee, Jim Scott, Cecilia Tacoli, Gustavo Gordillo, Robin Mearns and two anonymous reviewers were very helpful. I also want to acknowledge the influence of Andrew Steer, Gloria Davis, and two groups of graduate students at Boulder. The title of this paper was inspired by Amartya Sen's (1997) World Development editorial on Human Capital and Human Capability that captured so nicely my nagging concerns about the language of capitals and provided a way forward in the thinking that is the foundation of this paper. Final revision accepted: 20 April 1999.
} 
This paper is therefore an attempt to build a framework that approaches rural livelihoods and poverty without automatically linking their analysis to agriculture or natural resources. In developing its case, the paper builds on recent writing on environmental entitlements (Leach, Mearns and Scoones, 1998, 1999) as well as the wider literature on access to resources (Africa, 1989; Bryant, 1992, pp. 21-24; Ribot, 1998). It aims to develop these frameworks further in several ways. In the remainder of this introduction let me anticipate these different elaborations.

First, I argue that it is important to have a wide conception of the resources that people need to access in the process of composing a livelihood, perhaps especially in a context where peoples' livelihoods shift from being directly based on natural resources, to livelihoods based on a range of assets, income sources and product and labor markets. ${ }^{2}$ This leads me to consider livelihoods in terms of access to five types of "capital" asset ${ }^{3}$ - produced, human, natural, social and cultural capital (cf. Bebbington, Kopp and Rubinoff, 1997; Bebbington, 1997; Scoones, 1998; Carney, 1998). This conceptualization has a related benefit, perhaps more potential than so far real, of conceiving livelihood sustainability within a framework that could also be used for thinking of regional and national sustainability (cf. World Bank, 1996, 1997), thus suggesting elements of a framework that could link levels of analysis in research and practice addressing the relationship between environment, society and development (cf. Blaikie, 1989; 1985).

Second, the paper suggests that we need a framework that bridges the more materialist (cf. World Bank, 1990) and the more hermeneutic and actor-centered (cf. Chambers, 1987; Scoones and Thompson, 1994) notions of poverty and livelihood. ${ }^{4}$ We therefore require a notion of access to resources that helps us not only understand the way in which people deal with poverty in a material sense (by making a living), but also the ways in which: their perceptions of well-being and poverty are related to their livelihood choices and strategies; and the capacities that they possess both to add to their quality of life and also enhance their capabilities to confront the social conditions that produce poverty. In the framework advanced here, then:

(a) peoples' assets are not merely means through which they make a living: they also give meaning to the person's world. This is not to fall into the trap of voluntarism, for of course a person's assets are in large part determined by the structures and logics at work in economic and political spheres (see below). They are, however, also-to some extent - both reflections and components of the meaning the person has tried to create through their livelihood strategies. This meaning will then be one of several influences in subsequent decisions people make about their livelihood strategies;

(b) assets - or what I call capitals in this framework-are not simply resources that people use in building livelihoods: they are assets that give them the capability to be and to act. Sen (1997) has noted that the possession of human capital not only means people produce more, and more efficiently; it also gives them the capability to engage more fruitfully and meaningfully with the world, and most importantly the capability to change the world. The same is also true, in other ways, for the other types of capital. The framework thus understands these assets not only as things that allow survival, adaptation and poverty alleviation: they are also the basis of agents' power to act and to reproduce, challenge or change the rules that govern the control, use and transformation of resources (cf. Giddens, 1979).

In some sense, this framework thus sees assets as vehicles for instrumental action (making a living), hermeneutic action (making living meaningful) and emancipatory action (challenging the structures under which one makes a living) (cf. Habermas, 1971).

Third, and critically, to conceive of livelihoods as partly dependent upon households' social capital offers a more integrated framework for thinking about access to resources. Indeed, seen this way, the distinction between access and resources breaks down, ${ }^{5}$ because access becomes perhaps the most critical resource of all if people are to build sustainable, poverty alleviating rural livelihoods.

Fourth, it is important that a framework understanding poverty in terms of assets also incorporates an analysis of the economic, social and political relationships that create poverty and wealth, but in such a way that (i) understands these relationships as potentially contingent and subject to re-negotiation, and (ii) links this contingency to the capabilities that people have as a result of the assets at their disposal. Assets are thus as much implicated in empowerment and change, as they are in 
survival and "getting by." 6 It is in this sense that access and social capital are central elements to the framework. They are the concepts for analyzing the relationships and transactions between the members of a rural household and other actors-relationships mediated by the logics of the state, the market and civil society. As rural people try and access resources they do so through engaging in relationships with other actors who are both present but more often than not usually absent from the day-today activities of rural people. Indeed access to other actors is conceptually prior to access to material resources in the determination of livelihood strategies, for such relationships become almost sine qua non mechanisms through which resources are distributed and claimed, and through which the broader social, political and market logics governing the control, use and transformation of resources are either reproduced or changed.

The social capital debate helps develop this aspect of the framework, for it helps us understand how actors engage with other actors in the spheres of market, state and civil society in order to gain access to resources, to influence the de jure rules of access in a society, or to turn their assets into commodity bundles (cf. Sen, 1981; Evans, 1996). Building on this debate, the paper also argues that we ought not automatically link the access question to the notion of "conflict over access" (Bryant, 1992, pp. 21-24) - not for reasons of linguistic tone, but rather for reasons of empirical balance, for indeed, there may be as much initiative and collaboration in widening access as there is conflict in the process of securing it. It is therefore important to develop frameworks that capture all these dimensions of access, and not only the conflictual-they must capture both the dynamics of conflict emphasized by Leach, Mearns and Scoones (1998), and those of cooperation emphasized more by authors such as Evans (1996) and Tendler (1997).

Most of the paper elaborates these different aspects of the framework. In developing its arguments, the geographic focus of much of the discussion and many of the examples is the Andean region. The themes are, though, of far wider relevance for thinking about sustainable rural livelihoods and economies. First, the paper reviews the changing ways in which rural livelihoods and poverty have been debated and analyzed. The debates on rural livelihoods have-perhaps more implicitly than explicitly-come to demonstrate how the resolution of access to resources and institutional spheres is critical in determining the relative viability and sustainability of livelihoods, thus justifying a conception of livelihoods rooted in a notion of access. Second, I present the basic elements of the capitals framework, and then suggest several ways in which this framework could usefully be developed. The final section focuses on one of the five capitals in particular, suggesting ways in which the concept of social capital might help us elaborate the relationship between access, institutions and livelihood.

\section{WHY ACCESS TO RESOURCES? DEBATING PEASANTS AND LIVELIHOODS IN THE ANDES}

Access to resources has been a constant theme in debates on peasant (or campesino) ${ }^{7}$ economy and livelihoods in the Andean region. While some authors have laid far greater emphasis on the constraints on peasant access to resources, others have either been more optimistic about the possibility that this access might be widened, or about the chances of increasing the returns to the resources that households control. This section reviews some of the themes in these discussions. It pays particular attention to recent policy discussions regarding livelihood viability (for these revolve around the notion that peasants' limited access to resources greatly constrains the viability of their livelihoods), and to research on instances where rural people have in fact been able to improve their livelihoods - for this research shows that critical to these improvements has been the possibility of gaining wider access to a range of resources and improved access to other state, market and civil society actors.

\section{(a) From functional dualism to "los no-viables"-images of limited access}

Since the 1970s and 80s, much of the debate about Andean livelihoods and peasant economy has been heavily influenced by a not always easy) mix of concepts deriving from dependency, world systems, unequal exchange, and mode of production theory (de Janvry, 1981; Deere and de Janvry, 1979; Hindess and Hirst, 1975). While much ink was spilled in trying to define the parameters of a peasant mode of production as a precursor to understanding its internal dynamics, the general sense that emerged from much of this literature 
was that the campesino economy was tied to the wider political economy in ways that extracted surplus value from rural areas, that constrained peasant access to resources (primarily land) and that involved very unfavorable relationships between rural people and both the market and state. Under this set of relationships, the peasantry not only provided cheap food to the urban economy, but because their income was low and asset base limited, had to migrate periodically - thus also providing the economy with cheap labor. Such notions of "functional dualism" paralleled ideas of the labor reserve economy in southern Africa and work on the urban informal sector (Bromley, 1979).

These approaches to peasant economy have also influenced work on the environmental dimensions of sustainability. Drawing (not always explicitly) on the notion of a dual economy whose parts were linked in a relationship that was functional to the needs of the capitalist system, these studies identified two forces driving degradation (Durham, 1995). On the one hand was the degradation that derived from the progressive impoverishment of the peasant economy that led farmers to overuse resources and use unsustainable practices "rationally, and sometimes rationally in desperation" (Chambers, 1987). This was degradation resulting from survival oriented livelihood strategies. On the other hand was degradation deriving directly from the activities of capitalist enterprises operating with a relatively short time horizon, and consuming natural resources in order to transform them into financial resources. In these models the state supported these enterprises, offering or protecting different forms of natural and policy subsidy to their operations (and thus to the degradation of rural resources) (Durham, 1995).

This earlier analysis of the peasant economy was conducted under the policy contexts of import substitution industrialization-a context in which the state assumed an important regulatory and interventionist role. Thus, while pessimistic in analysis, there was an implicit notion that a "via campesina" or peasant path based on intensified, agrarian based rural livelihoods was still a possible and conceivable development option (Figueroa, 1990; Brush and Turner, 1987). By the early and mid-1990s there had been a shift of emphasis, apparently reflecting changes in both policy and mood. The policy shift is that of neoliberal economic reforms. These have prompted work on the impacts of these reforms on agriculture in general, and the small farm sector in particular (Kay, 1995; Gwynne, 1997; Weeks, 1995). Various studies have looked at the differing impacts of these policies on different types of producer and producer context (e.g., Enriquez, 1998). The shift of mood is that of a certain "defeatism" on the part of those who would have "taken the side of the peasants" in the past. In some cases, this defeatism is phrased in more empirical termsthat in the face of the macroeconomic shifts that are occurring in the region, a significant part of the peasant economy is in many instances "not viable." 8 In other cases it is phrased in normative terms - namely, that in a context of scarce public finances, the peasant economy ought not be seen as an object of public investment.

Together these changes seem to have led to a certain truncation of all the grander theoretical discussion of the 1970s and 1980s: in the 1990s, interpretations have been more empirical, more narrowly focused and less hopeful. While still in the pessimistic vein of the earlier arguments, these reflections on viability shed the theoretical notions of functional dualism. Indeed, the notion of "functionality" is often gone. In some conceptions peasants are seen as dysfunctional to the overall economic model because they control land resources that could be used more efficiently by capitalist producers-and/or because their production systems degrade land with consequent adverse downstream effects. Other conceptions, though conveying a far more critical conceptualization of a wider political economy that simply has no need for the campesino sector, can still frequently lead to the conclusion that this is a peasantry surplus to structural requirements, and that the policy (and theoretical) challenge is to understand the scope for alternative sources of livelihood in the urban sector.

Though only marginally an Andean country, the experience in Chile lies behind much of this shift in thinking. Throughout the Pinochet era of broadly neoliberal reforms, the Chilean government gave only limited support to an emerging sector of medium-sized capitalist family farms and invested little or nothing in the peasant economy (Berdegué, 1990; Kay, 1997). Support to this sector became largely the preserve of nongovernment organizations (NGOs). At the same time, the medium and large farm sector began to thrive - with certain crisis periods, as in the early 1980s-laying the ground for the oft-heralded miracle of Chilean 
agricultural transformation. By the time an elected government came to power in 1990, any idea of programs of asset (primarily land) redistribution had already been ruled out during the discussions of the pretransition agrarian commissions of the opposition parties. Instead, the new government opted to extend programs of technical, credit and other support, so that they would now reach the Chilean campesino - indeed the coverage of these programs has increased significantly (Berdegué et al., 1998).

The programs however, were being extended within an overall context of continued neoliberal economic policy and fiscal stringency. Soon, then - and within the context of an often tense relationship between a Ministry of Agriculture wanting to invest in the sector, and a Ministry of Finance wanting to limit such investment if it could not be shown as profitable - a language emerged that began to differentiate among so-called viable and nonviable peasants (los viables and los noviables). The argument was that a large part of the Chilean peasantry (some suggested 50\%: Sotomayor, 1994) were not viable - the definition of nonviability being based largely on the land and water assets that they controlled (Namdar-Irani and Quezada, 1994, cited in Kay, 1997). With such limited assets, it was argued that they could not conceivably become competitive production units capable of accumulating capital. As they were not viable, the argument continued, these peasants should not be the object of programs aimed at enhancing their productive capacity but rather ought be supported through social investment programs that would alleviate their poverty and ultimately facilitate their transition out of agriculture and into the urban economy. Others were yet more drastic, arguing that for most peasants, the money spent on programs of technical and credit support would have a far greater impact on rural poverty if spent on education (López, 1995). While the government did not take on board these more radical interpretations, policy toward the small farm sector nonetheless became one of promoting so-called reconversión or productive transformation (Kay, 1997). This reconversión involves investment in the productive potential of those units deemed potentially viable (according to the land and other natural resources to which they had access), in order to facilitate their transformation into competitive capitalist family farms by increasing their yields and/or their mix of activities (Kay, 1997). The noviables would instead receive other types of support (from ministries other than agriculture) that would ultimately aim to enhance their potential to become a productive proletariat (though this language was not necessarily that which was used). ${ }^{9}$

This notion of viability has subsequently spread through Latin America, and not least into the Andean countries. This "diffusion of a discourse" is partly due to the adoption of macroeconomic and agricultural policy frameworks to a greater or lesser extent based on the Chilean experience. It also reflects the influence of the principal agencies financing these policy transitions-agencies that have been significantly influenced by the Chilean case, and whose broader concerns for fiscal efficiency jibe well with the notion that rural productive investments should be very strategically targeted to areas where there is the potential for enhanced productivity. Thus, for instance, an Inter-American Development Bank report on social and economic development in Bolivia was able to ask: "Is Bolivia viable?" The report paraphrases the conversation that ensued among the team: "The reply came without question: 'It has to be viable.' Later the question was recast 'Is the altiplano viable?' This time there was discussion and the eventual reply was more nuanced: 'In some areas, yes' ", (IDB, 1996, p. 79).

Beyond this policy context, discussions of viability are themselves also a direct consequence of the very disappointing effects that rural development programs have had in ostensibly low-potential areas, such as much of the higher Andes (Zoomers, 1998; VMPPFMBanco Mundial, 1998). "Looking back over the history of international cooperation in the Bolivian Andes, one theme is constantly dominant: disappointment with the results of rural development programs" (van Niekerk, 1997, p. 2). In the light of these experiences, and his own studies of the impacts of NGO interventions in the Peruvian and Bolivian Andes, van Niekerk (1994, p. 319) himself comes to the conclusion that: "If the market is the determining factor in the definition of rural policy, Andean agriculture has two possibilities: to disappear, or to modernize violently to achieve competitive levels of productivity and production."-in short, the two prongs of Chilean reconversión. Van Niekerk goes on to suggest that neither of these options is likely in Bolivia and Peru today given the limits on 
public investment and the inability of the urban economy to absorb migrants; consequently, he says, the likely scenario is one of an "impossible" situation in which the peasantry continues to limp along, caught between migration and low-productivity agriculture.

\section{(b) Peasant viability and rural livelihood transitions in the Andes}

While these discussions might seem despairing, it is important to note two things. First, that within the general context of crisis, there are areas where people have turned things around, and where processes of agrarian accumulation have occurred in the campesino sector (Lehmann, 1986; Bebbington, 1997; North and Cameron, 1998). Second, it is important not to equate agrarian livelihoods with rural livelihoods. While many agrarian livelihoods might be in crisis, there may be other rural livelihood options emerging that also address households' material and human needs. This distinction is also politically important to make because the peasant nonviability argument is often closely linked to the idea that policy ought help people leave the land, and move to urban areas. Yet, if it can be shown that rural families are able to put together livelihoods that are less precarious than those suggested by van Niekerk (1994), elements of the notion of nonviability might be accepted without having to argue for permanent outmigration and loss of land. This argument is particularly critical to make in the case of indigenous groups for whom rural residence and relationship to land constitute important dimensions of their ethnic identity (Salomon, 1979; Korovkin, 1997): an identity whose maintenance may, beyond any material measure, be a critical determinant of their sense of being poor or not (see below).

This implies shifting our lens somewhat, and looking less at agriculture per se and instead focusing attention on the types of resource, institutional sphere and market type that families have accessed in the course of composing sustainable, non-agricultural rural livelihoods. This then makes it important to look in more detail at the varying types of livelihood strategy that are emerging in the Andes, in order to understand the types of resource access, capability enhancement (cf. Sen, 1997) and political economic factors upon which they have been based, and the conditions under which they may become more sustain- able and more poverty alleviating (the two are not necessarily the same). If a framework can be built that helps capture this, then this may help guide interventions, as well as offer a common language for analyzing the diverse types of livelihood transition that are occurring in the region.

Indeed, a quick review of Andean experiences suggests that while the notion of agricultural crisis may be real in a number of cases, there are also instances of agricultural intensification, or other types of livelihood transition that may offer elements of sustainable alternatives. The following looks at several of these transitions.

\section{(i) Capitalized family farms and agro- silvipastoral transitions}

Important insights into the possibilities for improved rural livelihoods have come from a body of work influenced more by Chayanovian and Boserupian theories of peasant economy than by more marxian positions (e.g., Netting, 1981, 1993; Turner and Brush, 1987). In the Andes, an early empirical concern of work from this perspective was the rise of the socalled "capitalized family farms" or CFFsfarms which constituted successful cases of accumulation and intensification in the household peasant economy (Lehmann, 1986; Llambi, 1989). These were farms that emerged from the medium-sized peasantry rather than the very poorest-and in that sense were the empirical precursor to the notion of "viable" units. Though understudied in the literaturegiven its primary concern to analyze expropriation and poverty-some commentators suggest that they are actually quite widespread in the Andes, and an important source of rural employment and of accumulation (Llambi, 1989). Common to the success of many of these CFFs have been: an ability to access land, finance and at times labor; an ability to gain a niche in higher value product markets; and the presence of different types of supportive state policy. Migration (often interpreted as an indicator of non-viability) has frequently played a role in generating funds for land purchase. These CFFs also seem more likely to emerge where large farms began to subdivide their property early in the century, or in more originally egalitarian agrarian structures (such as areas of colonization) where there was less likelihood of larger farms having appropriated all land and thus having kept a lid on land markets (Lehmann, 1986). 
Subsequent work began to suggest that similar styles of intensification were apparently possible for small producers also. While access to resources for the CFFs had been mainly through the market, state and kin networks, for small producers, more formal-and relatively strong-forms of organization along with external support have generally been more critical in opening access to knowledge, credit, irrigation, technical assistance and new markets (Bebbington, 1997; North, and Cameron, 1998; Hinojosa, 1998; Sinergia, 1998; Perreault, Bebbington and Carroll, 1998). In the cases of contract farming, the intermediation of commercial actors has been important in widening this access, albeit at considerable cost for peasant autonomy (Korovkin, 1992). Thus, while elements of the transition and resources accessed were similar to those of the CFFs, the mechanism of access differed in the case of small farmers, with intermediary organizations of state, market and civil society playing important roles.

\section{(ii) Rural proletarianization}

The presence of nonviable agricultural units has not necessarily led to the end of rural livelihoods. A significant feature of some regional economies has been the growth of a rural proletariat working on capitalist agricultural enterprises. The rise of fruit production in Chile brought particular attention to this phenomenon (Gwynne, 1997), but elsewhere the emergence of strong nontraditional agri-, flori- and horticultural sectors has similarly given rise to rural work forces elsewhere: such workers are sometimes urban based, and in other cases are members of peasant families (Korovkin, 1997). In many cases, this proletarianization does not lead to more sustainable livelihoods, especially when wages are low and health hazards high as a result of the use of agrochemicals in such enterprises (Stewart, 1996). Such jobs however, can at times resolve the rural residence/making a living dilemma, enabling people to stay in their communities through the complementary income coming from being a laborer in nearby agroenterprises (Korovkin, 1997). Thus, rather than instinctively criticize this option, it may be more appropriate to find ways of improving its contribution to livelihood sustainability. This may involve pressuring (or legislating) for greater workplace security and control of health hazards, support to workplace organization, special skills training and so on.

\section{(iii) Migration}

Where agricultural intensification has been limited, and other rural employment absent, the principal livelihood adaptation has been temporary or permanent migration. Indeed, the Andes is full of projects that have attemptedand failed - to stop this out-migration. In part this is because migration has been an element of Andean livelihood strategies for a long time; but it is also because migration is critical to the viability of rural peoples' livelihoods (Preston, 1997). Migration is often, of course, merely a survival strategy - in many contexts families scarcely scrape by, and the cost to the migrant is enormous (Chambers, 1987; Bebbington, 1993). But in some cases migration has allowed significant family accumulation. Talking of the special, but by no means unique, ${ }^{10}$ case of international migration in Cañar, Ecuador, Jokisch (1998) comments on the ways in which migrants' remittances from the United States allow the rest of their families not only to keep living in communities, but also to combine subsistence agriculture with a remarkable improvement of housing conditions. While rural investment in housing as opposed to productive activities might be considered far from ideal and be a result of a continuing absence of financial institutions or asset and product markets in rural areas, as much as a cultural preference, it is nonetheless a measure of accumulation. It is therefore informative to look at cases where migration has gone beyond a survival strategy and has become part of an accumulation strategy (either in the form of housing or productive investment), in order to understand how this has been possible. In these as well as other less extreme cases (Preston, 1998), it appears that a successful sustainable rural livelihood strategy that combines migration with subsistence production at home and continued control over land revolves around having the skills to enter higher paid labor markets in urban areas, and having the social networks to gain access to work opportunities.

\section{(iv) Rural industry}

In some areas rural industry has emerged and afforded other rurally-based livelihood options. The rise of apparel, leather and shoe-making industries in Tungurahua, Ecuador, for instance, has allowed families to combine home-based work in these industries with agriculture (Martinez, 1994). The impacts on rural income and health have been significant 
(North and Cameron, 1998). The textile industry has also come to dominate the rural economy and rural livelihoods in many communities in northern Ecuador, where relatively high value products have been made over a long period of time (Salomon, 1981). Though this has led to social differentiation, it has also allowed continued rural residence in areas of quite advanced land fragmentation. To be able to engage in such livelihoods, families need the skill to do the work required (a human capital issue) and the access to the intermediating agent (industrialists, traders, organizers of production networks) that links rural families to wider markets and chains of production. In particular, it seems that links to higher-value markets are important, and more able to withstand the effects of structural adjustment policy (North and Cameron, 1998).

\section{(v) Rural and peri-urban commerce}

Other groups in the Andes have been able to build rural livelihoods around commerce. In some cases this may mean a member of the family leaving for significant parts of the year, or permanently, in order to peddle products elsewhere, as in the case of the Colta region of Ecuador (Gellner, 1982; Tolen, 1995). Indeed, Colta is remarkable: in the midst of an obviously sad agrarian landscape one encounters two and three story cinder block, painted houses - the result of accumulation from trading elsewhere. These houses allow the rest of the family to remain in rural areas, or allow the family to come "home" periodically, and ultimately to retire. In other cases, the commerce is in nearby urban settlements - as in the case of Ayacucho where in under four years periurban/semi-rural women have been able to accumulate over 1 US\$ million of savings in village banks through their trade activities in Ayacucho city (D. Bebbington, 1999). ${ }^{11}$ In yet other cases, it is linked to contraband at international border areas (e.g., Puerto Acosta, Bolivia). Critical to these cases, it seems, are: the access to initial capital (often in very small quantities) to begin trading, an access often mediated through a micro-financial services organization; and involvement in networks that facilitate access to markets (Woolcock, 1998).

\section{(c) Elements of a framework: access to capitals and spheres of access}

The ways in which people compose rural livelihoods in the Andes are multiple and increasingly they have very significant nonagrarian components (cf. Ellis, 1998). Across this diversity, however, one can detect common themes in those instances where there has been some success in composing a viable livelihood. These themes revolve around issues of access: more viable rural livelihoods appear to be characterized by a relative success on the part of households and their members to sustain or increase their access to:

-different resources, such as credit, land, skills, labor etc. depending on which of them are most relevant to the type of livelihood that people are composing. It is to be noted, though, that in some cases people sacrifice one or another of these assets (especially land quality) in order to build up another asset base more appropriate for their overall livelihood strategy;

- different opportunities to turn those resources into sources of livelihood enhancement (e.g., by accessing new labor and product markets);

- means of enhancing the existing ways in which those resources contribute to their livelihoods (e.g., by obtaining better terms in transactions through a renegotiation of the power relations that underlie those transactions; cf. Ribot, 1998); and

- kin and ethnic networks, social organizations, intermediate state and nongovernmental organizations, and intermediary market actors. Access to such institutions and relationships has been important in securing the three other types of access.

Conversely, where rural people have not been able to improve their livelihoods, the principal reasons seem to derive from a failure or inability to: defend their existing assets; ${ }^{12}$ identify and secure opportunities to turn assets into livelihoods; or protect existing ways of turning assets into livelihoods (e.g., by losing a place in a market). An important factor in such failures to counter the forces that create poverty has been the limited ability of people to build up, and to draw upon, networks and links with state, market or civil society actors that would otherwise have helped them access, defend and capitalize on their assets.

If we were, then, to build a framework for analyzing poverty reducing rural livelihoods, at a minimum it would need to address:

- the diverse assets that rural people draw on in building livelihoods;

- the ways in which people are able to access, defend and sustain these assets; and 
- the abilities of people to transform those assets into income, dignity, power and sustainability: or in other words, to transform them into

- consumption levels that reduce their poverty;

- living conditions that imply an improved quality of life according to people's own criteria;

- human and social capabilities to use and defend assets ever more effectively; and

- an asset base that will continue to allow the same sorts of transformations.

Ideally, the framework should also be conceived in such a way that reaches across scales of analysis, in two ways in particular. It should help us address the relationships between intrahousehold, household, regional and macro economies; and it should incorporate the relationships that households have with institutions and organizations that operate at wider scales, and which in general constitute the channels through which development intervention occurs.

By phrasing the issue in this way, we can conceptualize sustainable rural livelihoods in terms of recent debates on access to resources (Berry, 1989; Blaikie, 1989), asset vulnerability (Moser, 1998), and entitlements (Sen, 1981), and in such a way as to extend recent attempts to develop such a conception (Chambers, 1989; Moser, 1998; Leach, Mearns and Scoones, 1998). The suggestion is that one part of a useful heuristic framework (see Figure 1) would conceive of livelihoods and the enhancement of human well-being in terms of different types of capital (natural, produced, human, social and cultural) that are at once the resources (or inputs) that make livelihood strategies possible, the assets that give people capability, and the outputs that make livelihoods meaningful and viable. ${ }^{13}$ The second part of this framework (Figure 2) focuses on household and intrahousehold level forms of engagement with

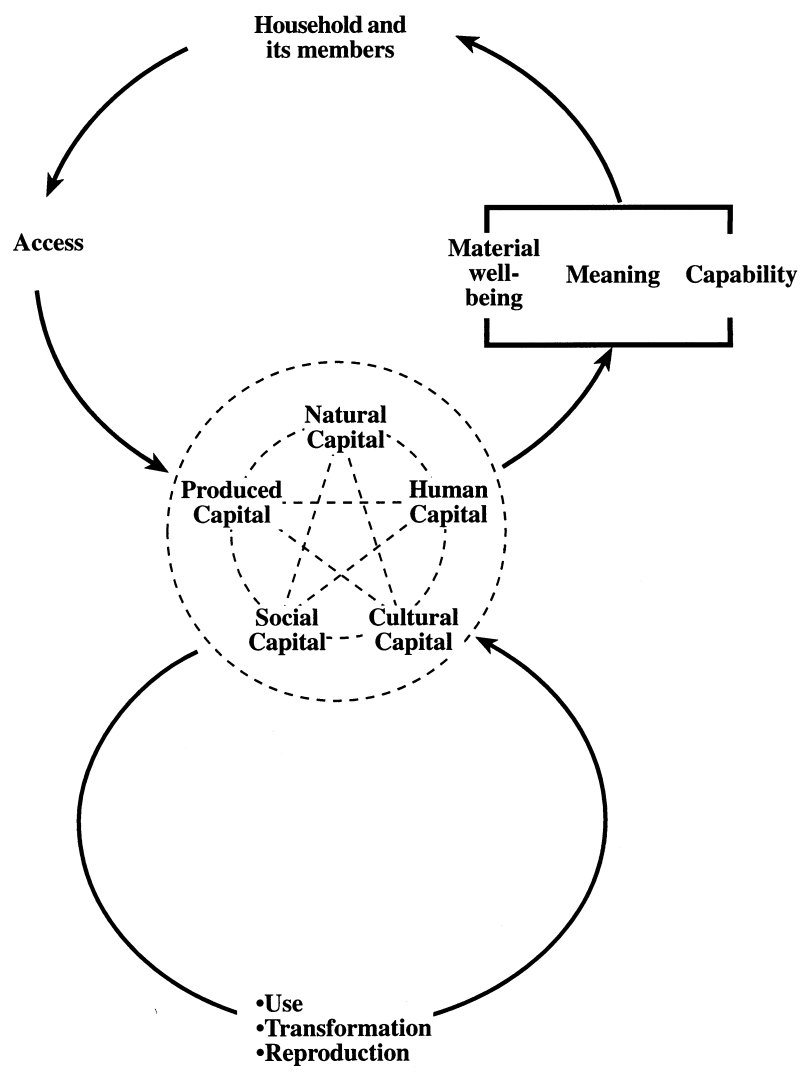

Figure 1. Assets, livelihoods and poverty. 


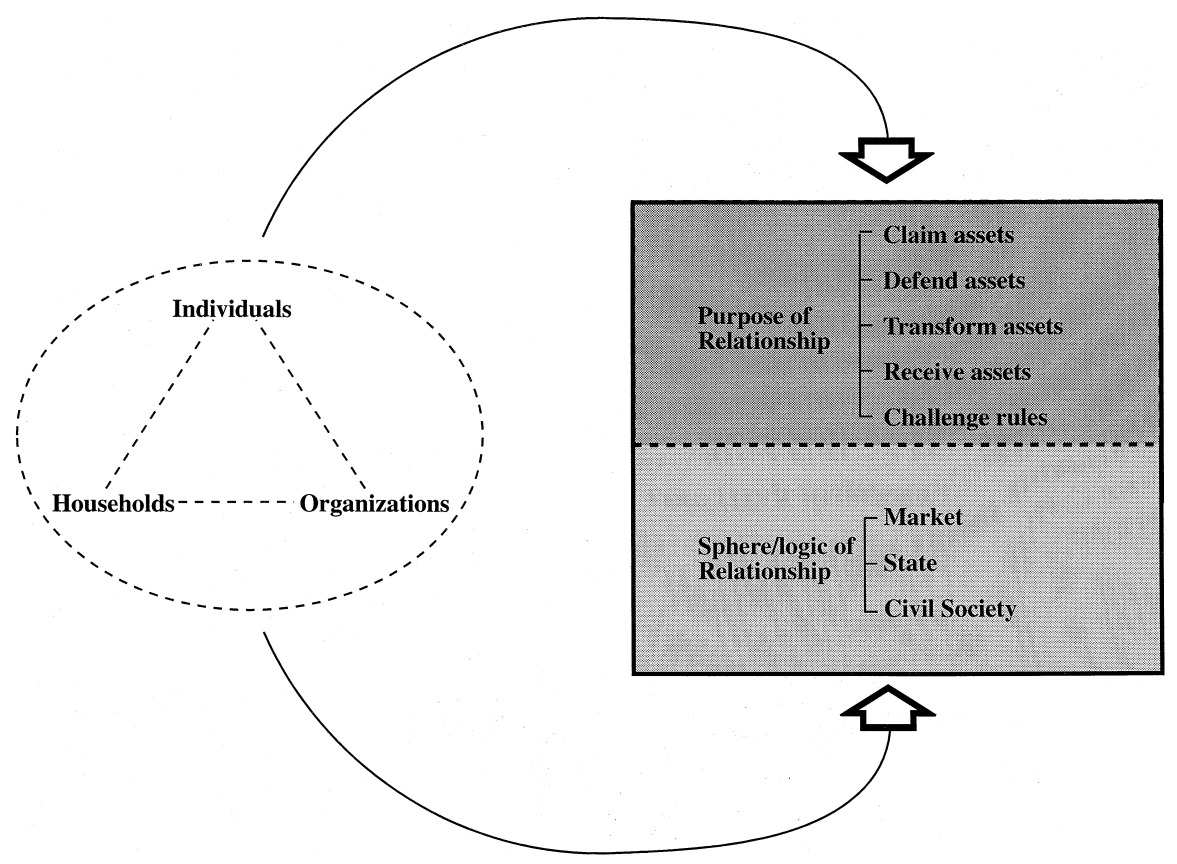

Figure 2. Relationships of resource access, use and transformation.

market, state and civil society actors and relationships, and the implications of these engagements for the distribution and transformation of assets. We now turn to this framework.

\section{WIDENING THE LENS: SUSTAINABILITY AND CAPITAL ASSETS}

In a short paper Serageldin and Steer (1994) suggested that we could think of sustainable development in terms of patterns in the accumulation of and substitution among four different types of capital (see also World Bank, 1996). They argued that for a long while, dominant notions (in the World Bank, but also beyond) had equated development with economic growth; hence the only indicator of interest to development planners (and Banks) had been expansion of produced capital. ${ }^{14}$ Subsequently, human capital was also recognized as critical to development and poverty alleviation. The 1990 World Development Report (WDR) thus argued that development (seen through the lens of poverty reduction) ought be pursued through a joint strategy of fostering macroeconomic growth and investing heavily in people (above all in education). ${ }^{15}$
As the World Bank was fashioning this statement, however, it and other agenciesunder the pressure of lobby groups and its own experience-increasingly came to recognize some of the adverse environmental impacts of growth. ${ }^{16}$ Thus, claim Serageldin and Steer, the notion of natural capital began to take a place, albeit subsidiary, alongside those of human and produced capital. Then finally, since Putnam's (1993) study of civic traditions, democracy and regional development in Italy, one more "capital" has been added (with more rapidity than conceptual clarity) to this growing list of capitals: social capital. Putnam suggested that the critical factor in explaining regional differences in government effectiveness and economic performance was to be found in corresponding regional differences in social structures and networks. In areas where social structures are more "vertical" and based on authority relations, then citizen capacity for collective action is limited, and access to and influence over state and market are far weaker. Conversely, he argued, those areas with more efficient, effective and inclusive governments and economies were characterized by more "horizontal" social relationships (based on trust and shared values), and higher levels of participation in social organizations and 
networks that cut across the boundaries between different institutions and social groups. These endowments he termed social capital.

If this was so, argued Serageldin and Steer, then sustainable development could be thought of in terms of changes in the overall stock of these four types of capital, and the changing composition of this stock. If "development" implied an overall increase in the capital stock, the relative "sustainability" (and indeed quality) of that development depended on the substitutions that occurred among the types of capital. They then go on to describe four types or levels of sustainability in terms of these four types of capital, and though we can argue with the very value-laden terms they use to describe four types of sustainability, they catch much of the debate about styles of types of development-for much argument about development is about the "level" of sustainability to which different groups aspire. ${ }^{17}$

Such a framework draws on ideas derived from early experiences in environmental accounting (cf. Barbier, 1994; World Bank, 1997) that have aimed to include measures of change in natural capital in national accounts to give a fuller sense of the environmental costs hidden in certain measures of growth. The hope, clearly, is to extend such analysis by developing measures of social capital that could also be included in national accounts and ultimately models that could determine the contributions of different types of capital to growth or poverty alleviation (cf. Grootaert, 1997).

Of course, the task of identifying viable (and agreed upon) indicators of social (and natural) capital is Herculean. Nonetheless, if only as a heuristic, the framework is a potentially intriguing way of making explicit the tradeoffs between economic growth, human development, social integration and environmental integrity that are implied by different development options. Indeed, we could talk of styles of development which opt for different mixes of and degrees of substitution among the different types of capital: not only as inputs to development, but indeed as the outputs that give both meaning and resources to people.

This final point opens up a number of ways in which this framework can be elaborated. Serageldin and Steer (1994) are clearly thinking of national development accounts as they elaborate their framework. Furthermore, they-and those who have elaborated the framework inside the World Bank-are apparently thinking of a sort of extended production function in which "development" (ultimately measured by income or expenditure: Knack and Keefer, 1997; Grootaert, 1997) is a function of produced capital assets, human capital assets, natural capital assets, and social capital assets. While this may be a helpful starting point, if such a framework is to engage other writing on poverty, livelihoods and development and link it to discussions of viability, it can only be part of our understanding. The following subsections suggest elements of such an elaboration around notions of: geographic scale; livelihoods and poverty; place and cultural capital; assets and capabilities; and access.

\section{EXTENDING THE SCALE: CAPITAL ASSETS, QUALITY OF LIFE AND HUMAN CAPABILITY}

\section{(a) Livelihoods, regional economy and national accounts: assets, scale and justice}

While Serageldin and Steer apparently cast their framework at the level of the macroeconomy, it can equally be applied to regional economies. Indeed, if it were then possible to develop a suite of indicators for each of the different assets at these different scales, it might be possible to suggest not only the tradeoffs between different types of capital at a macro level, but also the different forms that these tradeoffs take across regions. This might allow a framework for linking macrodevelopment choices with analyses of social, geographical and environmental justice. It would be possible to talk about how patterns of asset growth and loss resulting from particular policies vary across peoples and places and indeed across groups within households.

Household and individual livelihood strategies might also be thought of in terms of access to these types of capital (Bebbington, Kopp and Rubinoff, 1997; Scoones, 1998; cf. Moser, 1998). As the Andean examples discussed earlier all suggest, Andean livelihoods now depend on a very wide range of assets, in some cases more natural resource related, in other cases more human resource related, and in most cases, social capital related. The principal assets that people draw upon in building their livelihoods thus vary across space and also across different social, gender and ethnic groups. If this is so, it becomes important to 
have a clearer sense of the most important assets for different people in different places in order to identify the most useful (and most damaging) sorts of public investment in such areas.

As a simple, but significant example: many projects in the high Andes have aimed to address poverty by working with agricultural technology, erosion control methods and other interventions related directly or indirectly to livelihoods based on natural resources. Yet oftentimes the families with whom they have aimed to work have depended primarily on migrant remittances for their livelihoods rather than on agricultural income. If this is so, then other types of support would have been far more appropriate. The hypothetical range of options here is obviously wide. Some options would emphasize investment in human capital more than produced or natural capital, for instance: training so that people are able to secure better and healthier jobs in the urban labor market; improved health care to increase migrants' resilience to environmental stresses; investment in education and nursery schools to increase children's long term capabilities; etc. Other options might emphasize investments in social capital as more appropriate. Social capital might, for instance, facilitate increased income for migrants, more rapid and safer transfers of remittances to rural areas, or more productive use of remittances once transferred to rural areas. In the first case, strengthening networks and institutions for accessing and sharing information among migrants on labor and petty trade markets might be appropriate, as might strengthening organizations that demand work safety for casual labor. Creating nonformal institutional mechanisms, such as money wiring services, for the transfer of resources from urban to rural locations, might be an appropriate response to the second challenge. ${ }^{18}$ And third, to foster more productive use of remittances in rural areas, strengthening rural financial institutions and village banks might be appropriate means of increasing the return on remittances for depositors, and turning them into credit possibilities for those wanting to invest in rural productive activities (such as agriculture, livestock or peri-urban trading etc.). In short, institutional and human investments largely unrelated to agriculture and often outside rural areas might be a more appropriate response to agricultural stagnation than yet one more erosion control or seed improvement project.
These different assets also clearly interact as people use and transform them in their livelihood strategies. On the one hand there are interactions within each type of asset: certain forms of human capital, for instance, will have more mutual synergy than others. At the same time, each asset clearly interacts with the others. Such interactions may be synergisticas in the case of womens' adult literacy programs around which groups formed which subsequently undertook village banking activities. ${ }^{19}$ Interactions may also be destructive: as when investments of financial capital have detrimental influences on environmental and social quality; or where financial capital is produced in ways that undermines social capital (e.g., fostering growing anomie, or violence), weakening the social networks through which people access resources of various types. ${ }^{20}$ In this sense, the separation between the inputs and outputs of a livelihood strategy is only artificial: the environment that an income earning strategy helps build (or destroy) and the social networks it helps create (or weaken), in turn affect any subsequent income earning activity.

If it were possible to map out the different assets that people draw upon in their livelihoods, then this would help improve the effectiveness and relevance of public investment. At the same time, though, rural peoples' livelihoods may be shifting because they are losing access to certain assets as a result of either ecological processes (e.g., demographic increase) or macroeconomic policies and the economic strategies of other actors. Thus, it is critical — as Yapa (1998) rightly insists - not to focus the poverty question only on an assessment of the poor. It is equally important to relate changing livelihood dynamics among the poor to the changing assets of other actors. People may be migrating more because they have lost access to land, water or forests as a consequence of the acquisition of those assets by other actors - acquisitions that in turn may be promoted by certain policies. Examples here are many: a mine opens upstream of the water supply of Andean communities; an intensive flower producer in the Inter-Andean valleys takes water that was previously used by upslope communities; oil wells are sunk in indigenous hunting and fishing grounds in Amazonia; etc.. In such cases, rather than identifying investment in migrant skills as a means of improving rural livelihoods, a mapping exercise showing the ways in which 
assets controlled by different actors undermine assets of poorer groups would instead (or also) suggest it was more important to invest in peoples' capability to control and defend assets (cf. Leach, Mearns and Scoones, 1998), raising the issue of how to invest in social capital instead of human capital (cf. Bebbington, 1996).

(b) Access, poverty and sustainability: assets as instrument, assets as meaning

The Serageldin and Steer (1994) framework, and attempts to elaborate it, can justifiably be questioned on the grounds that their implied understandings of poverty are largely economistic: measured in terms of GDP (Serageldin and Steer 1994; Knack and Keefer, 1997) or household income and expenditure depending on the scale at which they are applied. ${ }^{21}$ Yet, poverty is more than this, and so any notion of the links between livelihood sustainability and rural poverty must also be wider. Indeed, the notion of livelihood in some sense cuts across what have been perceived as two opposed views on the nature of poverty (Baulch, 1996; Moser, 1998). At one pole are those approaches to poverty that aim to measure it objectively in terms of expenditure, income or some other quantitatively defined indicator (Grootaert, Kanbur and Oh, 1997). At the other pole are the approaches that aim to see poverty through the eyes of the poor, arguing that it is as much a subjective experience as it is an objective state, and that participatory research methods offer the best means for assessing poverty and capturing what people themselves identify as its principal dimensions and indicators (Chambers, 1989; Chambers and Conway, 1992). While much of the influential writing using the terminology of livelihoods came from this latter school (Chambers, 1989; Chambers and Conway, 1992; Scoones, 1998), the notion seems to capture both the objective dimensions of "having to make a living to get by" as well as the subjective dimensions of the conditions in which one lives. Income, expenditure and the experienced quality of life are all somehow implicit in the notion of livelihood. ${ }^{22}$

Elaborating this point, poverty has different dimensions, and up to a point (but only up to a point) Serageldin and Steer's (1994) four capitals capture its environmental, income, human capital and social dimensions. In their livelihood strategies, people make certain choices as regards the substitution between these different dimensions of poverty (often of course under conditions of severe constraint). Thus at times, people may decide (again, under great constraint) to live in areas of severe pollution, violence, or anomie, in order to earn a living - a decision to suffer environmental and social dimensions of poverty in order to meet immediate monetary needs. At other times-more often in rural areas-people chose to desist from migration as far as possible in order to be in a calmer, cleaner environment closer to familiar kin, community and religious institutions, but at a cost of reduced monetary income. In like vein many livelihood decisions involve a choice to overconsume a particular capital asset at a given moment. This may be natural capital (e.g., by overcropping); social capital (e.g., by benefiting from organization/ family/kin networks but not contributing to them and so not attending to their maintenance); produced capital (e.g., by drawing down on financial savings, or not maintaining the value of savings, such as houses, vehicles, draught animals); and human capital (e.g., by sending kids to work rather than school, or by moving into work that causes ill health etc.). Livelihood strategies are attempts, from existing and often severe constraints, at a continuous management and modification of these substitutions, tradeoffs and draw downs on different capital assets. How these tradeoffs are made, and which ones are preferred, vary across the life cycle, and also across the short term. At certain points the resulting strategy may seem sustainable, at other points not.

The different capitals are thus not only inputs to livelihoods and development strategiesthey are also their outputs. Thus their changing composition ought be considered not only in sustainability terms (à la Serageldin and Steer, 1994) but also in poverty terms. ${ }^{23}$ Actors at different scales opt to address certain dimensions of their poverty, and not others, certain dimensions of sustainability and not others. How they make this choice depends on what development, poverty and livelihood mean to them, as well as the constraints under which they make these decisions and the power relations at play. We therefore need to be concerned not only with the ways in which assets are translated into income, but also with their impact on peoples' sense of their well-being. In this sense, peoples' capital assets affect poverty status and quality of life by affecting human experience as well as income. Keeping this experiential dimension of poverty and 
livelihood is thus critical if interventions are to be relevant.

\section{(c) Cultural capital: place, practice, poverty}

This discussion returns us - partially - to an observation made earlier: namely that running through many livelihood strategies in the Andes is an apparent determination to gain and/or maintain access to land as part of a wider concern to maintain some form of rural residence. ${ }^{24}$ Residence appears to be associated with the maintenance of a range of cultural practices that are valued for their meaningfulness: participation in fiestas (e.g., Rasnake, 1988), in certain forms of agricultural labor (Tolen, 1995), in volley ball games on the communities' court etc. Over and above the meaningfulness of a particular set of assets, then, there is a meaningfulness associated with the set of cultural practices made possible (or constrained) by the patterns of co-residence and absence linked to certain livelihood strategies. This becomes one more (very important, though understated) dimension of the meaning of poverty or wealth to rural people themselves. It is therefore necessary that analytical frameworks are explicit in capturing this on the "output" side of their understandings of development-particularly given how easily these practices can be destroyed by intervention and policy.

Beyond being simply meaningful, such practices are, however, also enabling and empowering. They enable forms of action and resistance that the other four types of capital would not, alone, make possible. They can also be the basis for the maintenance and enhancement of each of the other types of capital (Kleymeyer, 1993). Through fostering certain forms of identity maintenance and particular patterns of interaction, they enable, inspire and indeed empower. They are another important "input" to livelihood production and poverty alleviation.

There is, thus, a conjunction between place and the reproduction of cultural practices that are important inputs to and outputs of livelihood strategies. These practices are not the same as social capital - though they do clearly depend on its existence in order to foster the conditions of social organization and spatial propinquity that allow many of these practices. Though adding another capital to an already growing, and potentially confusing list of capitals, such observations imply that the notion of cultural capital might usefully be added to the framework's asset types. This is a form of capital that will clearly never be quantified, nor should be: but making its role, importance and potential loss explicit in narrative form remains critical if external notions of poverty are not to be too divorced from rural peoples' conceptions.

\section{(d) Capitals and capabilities: the rural poor as agents of change}

The notion that cultural capital is empowering raises the critical point that peoples' assets are not only a source of sustenance and meaning - they are also a source of power. Indeed, Sen (1997) has recently suggested jettisoning the terminology of human capital as overly economistic, referring to the worth of human capital development only in terms of its contribution to productivity. Human capital development contributes, he insists, to the quality of life in many more ways than this: a range of ways which he sums up as "human capability." The ability to read and write, for instance, not only enhances people's ability to secure better jobs and do them more efficiently - it also enhances their ability to engage in discussion; to debate; to negotiate; to add their voice to the multitude of voices influencing household, local and national discourses on development etc. All these changes improve the quality of peoples' lives in ways that simple income, GDP or Human Development Index measures chronically underreport.

Perhaps more important, Sen argues, is that these capabilities enhance people's ability to be agents of change. They enhance people's ability to question, challenge, propose and ultimately usher in new ways of doing things. This enhances people's capability to change the rules of the development game - a change, which as Yapa (1998) and many others remind us, is a sine qua non of genuine poverty alleviating strategies. Thus, in considering measures of human capital's impact on development or livelihoods, it is important to remember that they always understate the significance of such investments.

Sen's comments regarding human capital can equally be made for social capital. Once again, the Andean examples, and many others, have shown how networks and organizations play a vital role in helping people act to improve their livelihoods, mobilize assets, and defend them. At the same time, they often give fora for 
people to discuss, have voice, enjoy interaction, question, debate etc. They thus add to the quality of life above and beyond their simple impact on poverty and income indicators, and are critical in enhancing rural people's capacity to be their own agent of change. These points are elaborated in the following section.

\section{ACCESSING, DEFENDING AND TRANSFORMING: CAPITALS, CAPABILITIES AND SPHERES}

Along with the notion of the five capitals, the second element of the framework suggested here is the familiar trinity of state, market and civil society (Figure 2): or more precisely the relationships between rural people and other actors who operate within these spheres. It is through such relationships that people (and their organizations) aim to reassert or renegotiate the rules (as defined within each of the spheres) governing access to resources in society: for each sphere has its own logics ${ }^{25}$ influencing the distribution, control and transformation of assets. Through these relationships, people also aim to defend their assets: by investing them in commercial markets, by mobilizing civil society actors to protect budgets for rural education etc. People also act through such relationships to defend or enhance the benefits they derive from their assets by transforming them. They may do this by selling them, loaning them, exchanging them or engaging in some form of transaction that allows them to enhance the commodity bundles and income streams that can be derived from them. ${ }^{26}$ These are also the relationships through which people struggle to improve the "exchange rates" that govern this transaction so as to increase the entitlements that their endowments will generate for them-e.g., by trying to increase the prices paid for forest products, or by seeking certification for organic products.

As each sphere operates according to its own logic, this sets the limits of what can and cannot be achieved through acting within that sphere (Ostrom, 1994). Thus, what can be done to enhance livelihoods and access to resources by engaging in relationships within the market sphere is limited by basic commercial logic; what can be done through engaging with the state is constrained (and enabled) by the ways in which the state works; and what can be achieved by collective action and engaging with other civil society actors is structured by the range of benefits and limits of this form of action. Thus it is almost certainly the case that being effective in enhancing livelihoods requires competence to manage relationships and transactions in each of these spheres, taking advantage of what can be achieved through one sphere, and complementing it with actions in the other spheres.

People's ability to gain access to those spheres, is in turn greatly affected by the capabilities they have as a result of their initial endowments of the different types of capital asset. For instance, people with significant endowments of land (natural capital) or financial resources (produced capital), or strong social networks (social capital) and university degrees (human capital and social capital) are in general better able to gain access to the institutions of the state and market and thus influence their subsequent effects on patterns of access - in short they are more powerful. It then becomes interesting to understand the conditions under which people with less endowments may be able to enhance their access to the actors operating within these different spheres, and the ways in which the organizations may begin to act more in favor of those with fewer assets, and less power. While a marxian perspective on class would argue that the distribution of material resources (natural and produced capital) will determine how the state and market function, and thus how questions of access are resolved, here I will follow those such as Berry (1989), Evans (1996) and Ribot (1998) who suggest - though this is certainly not the terminology they all use to do so- that social and cultural capital can also be vitally important in determining access to resources. This is important, because it begins to identify these as critical spheres for intervention to take into account if the goal is to alter the ways in which state and market typically affect the distribution of assets and the ability of rural people to use them. In closing, I therefore focus on the ways in which social capital can enhance access to other actors governed by the logics of state, market and civil society, and thus affect livelihood sustainability and poverty.

\section{(a) Assessing the impacts of social capital: the problem of causal mechanisms}

Social capital belongs to that alarmingly long list of terms in development that are 
notoriously difficult to define, above all in a commonly agreed upon manner (Harriss and de Renzio, 1997). In perhaps the most exhaustive review discussion of the concept to date, Woolcock (1998) defines it as "a broad term encompassing the norms and networks facilitating collective action for mutual benefit" (p. 155). This is relatively consistent with the definitions of such originators of the concept as Coleman and Bourdieu. It is also akin to Putnam's (1993) definition of the term in the work that propelled the concept to popular fame, though in practice Putnam "measured" social capital primarily by counting civic organizations. This is significant, because although most authors will tell you that what they mean by "social capital" is networks and norms such as trust, these are notoriously difficult to identify and assess, and so much work ends up inferring the existence of the norms and networks on the basis of actual collective action, generally in the form of organizations and groups (e.g., Narayan and Pritchett, forthcoming; Bebbington, 1997). Social capital thus appears to be a phenomenon whose indicators are largely surrogate and indirect. ${ }^{27}$ Nonetheless, it has touched a nerve, just as the terms sustainable, and livelihood have, and in that sense seems to convey to "experts" a sense of something very important to society.

Given the difficulties of defining social capital, and the differing ways in which it is used in the literature, we need to be careful before attributing too much weight to empirical results linking social capital, poverty and livelihoods. There is however, a slowly accumulating body of evidence that suggests a relationship between social capital and poverty, though different studies do not necessarily agree on which indicators of social capital best predict this relationship. Some of this work has been conducted at a macroeconomic level, and finds correlations between national income and social capital measured as "trust," civic norms and the presence of national institutions that are effective in protecting property and contract rights and that in a sense mandate trust and so restrain predatory actions (Knack and Keefer, 1997). Conversely, this study (of 29 market economies) finds no relationship between per capita income and level of associational activity, and thus stands in contrast with Putnam's (1993) work that identified membership in civic associations as the critical indicator of social capital and as directly causal of improved economic and government performance. ${ }^{28}$ Recent, more detailed, household level work however supports Putnam (rather than Knack and Keefer) in suggesting a correlation between membership in organizations and income. On the basis of a 5,000 household survey, Narayan and Pritchett (forthcoming) argue that one standard deviation in their social capital index (based on membership of village organizations and the social inclusivity of those organizations) leads to a $20 \%$ increase in household expenditure. More interestingly, they argue that the village-level income effects of aggregate household membership in organizations are even more significant than the household income impacts, suggesting that most of the income benefits of membership in groups are felt collectively rather than privately. Comparing data from the states of India, Morris (1998) comes to similar conclusions, as does early analysis of on-going household level work in Bolivia, Burkina Faso and Indonesia (Grootaert, personal communication).

These studies identify tantalizing correlations between social capital and poverty (albeit only in its economic dimension), on the basis of which they infer causal relationships. But in fact they say little or nothing about the actual causal mechanisms at work. Nor do they help us know whether certain types and characteristics of organization and networks are more likely to have positive impacts than others, or whether impacts can be positive or negative, depending on the status of other contextual factors - as authors like Woolcock (1998) suggest is very probably the case. It is only with this sort of information that we can begin to understand the more precise ways in which, through its influences on both access to resources and to other actors, social capital affects poverty and livelihood: and only with this type of information can more sensitive guidelines for action and intervention be inferred.

\section{(b) Social capital and access: the missing causal mechanism?}

While survey-based work on social capital has been more oriented toward showing the economic/income effects of social capital rather than the mechanisms through which these effects occur, more ethnographic work has tended to focus on causal mechanisms without necessarily showing that these have in fact affected rural peoples' poverty (e.g., Fox, 1996). Nonetheless, this work is instructive because it 
does suggest ways in which social capital apparently facilitates forms of action that one would expect enhance peoples' livelihoods. In general, these actions can be understood as enhancing people's ability to access and defend resources, transform them into income, and access institutions and organizations in the spheres of market, state and civil society in such a way as to facilitate resource access, defense and transformation. Importantly, this can happen through actions either of rural people or of external organizations: from the inside out, and from the outside in (cf. Woolcock, 1998).

\section{(i) Social capital and widening access from the inside out}

Most of the work on social capital emphasizes the different ways in which social relationships can be mobilized from within civil society to manage resources of various types and to engage with other actors. We can organize this work around the notion of accessing, claim making, defending and transforming assets. Some of this work has demonstrated clearly how certain types of communitylevel relationships - often ones based on shared cultural identity, frequent confrontations with other groups, shared experience of discrimination and strong intragroup communication (Portes, cited in Woolcock, 1998; also Durston, 1998) - can play important roles in facilitating member access to local resources of various types. Similarly, as Katz (forthcoming) shows for Guatemala, such relations can secure and defend private as well as group natural resource property rights, and thus protect those resources from other users. They can also lead to more efficient use of resources, through fostering coordinated action (as in the case of water: Lam, 1996). This is not to say that such relationships are always or even usually the norm in communities (Leach, Mearns and Scoones, 1998; McCay and Jentoft, 1998); their potential effects, though make it important to understand how such relationships come into being.

Also at the local level, networks of trust and mutual accountability linking individuals in communities (not usually all the community) are critical in helping break the problem of access to financial capital. They have been the basis of successful, self-sustaining and often growing forms of local banking (indeed, Putnam, 1993, uses rotating savings and credit associations as his principal analogy to demonstrate the nature of social capital). In this way, by facilitating access to credit and the possibility of saving, this form of collective action facilitates an accumulation of produced capital, and through this a more effective participation in certain markets. Too little is yet known, though, about the final livelihood (and distributive) impacts of this.

Moving up a level, other work has demonstrated the importance of strong regional organizations with networks linking them to other civil society and government actors. These can play important roles in preventing other actors from expropriating natural resources (such as forests or intellectual property), in facilitating access to other types of investment (e.g., in education, health) by demanding and/or managing such programs, and in gaining a more permanent presence in certain rule defining and decision making fora in the state and in civil society (Fox, 1990; Bebbington, 1996). Similarly, strong organizations with networks linking them to other market actors can help open up market possibilities to rural producers that otherwise they would not have, and can in this way increase their ability to turn their assets (of whatever type) into income streams (North and Cameron, 1998; Bebbington, 1997). In some Andean cases, these networks have subsequently become part of the local state (Bebbington and Perreault, 1999), and thus been able to influence-however marginally - the regulation of resource control and of local markets (thus influencing the benefits to be derived by rural people as they transform their assets through market exchanges). Also at the supracommunal level, networks of far less formalized relationships have played an important role in establishing and sustaining alternative, nonagricultural forms of economic activity. The rise of a rural weaving industry in Northern Ecuador, or of the garments and leather sectors in central Ecuador, demonstrate the importance of these networks in organizing production, and allowing people to become involved in these activities and market spheres (Ramón, 1988; Martinez, 1994).

Finally at the national level, especially strong social capital, in the form of regional and national organizations and their links to government officials, can be a mechanism through which rural people are able, collectively, to have an influence on the overall rules governing the distribution of public investment of various types, and the defense and use of natural capital (Fox, 1996; Bebbington and Perreault, 1999). 
(ii) Social capital and widening access from the outside in

As Tendler (1997) notes, most of the work on "top-down" institutions has been critical almost by definition. Yet recent work has shown how under certain conditions government actors have been able to widen resource access and control in rural areas, through processes that might be thought of as building social capital. In most cases, this has occurred in the context of service provision (Ostrom, 1996; Tendler, 1997). In some instances, government has been able to build synergistic relationships with local organizations that increase the quality and coverage of the provision of services, in turn enhancing family assets-particularly human capital and produced capital assets. In the process, these initiatives also build up their social capital assets to the extent that the collaborative relationship built between government and social organization persists and facilitates other forms of collaboration and engagement. In other cases, government agencies-or more accurately key, pro-poor individuals inside the agencies - have helped build up civil society organizations, enhancing their capacities to coordinate with, or exercise pressure on, government and other organizations in the pursuit or defense of access (Fox, 1996).

These synergistic relationships, while usually with formal organizations, can also be with less formal networks built up largely as a result of the government's action. Tendler and Freedheim (1994) show how a preventive health program in the state of Ceará in Brazil was turned around through a concerted effort on the part of government - again at the initiative of key, critically placed individuals - to develop such networks linking it to rural and urban dwellers. The result was a $36 \%$ decline in infant death rates, a tripling of vaccination rates and a greatly enhanced capacity and functioning presence of government health centers in almost all the state's 178 municipios. (Tendler, 1997, pp. 21-22). This occurred as a consequence of state efforts to increase the legitimacy of the health service on the one hand, to widen its points of contacts with communities, and finally to create among Ceará's citizens an expectation of good service - and thus a constituency that could exercise some social control in demanding good service through the now widened web of contacts linking it to the government program.

Thus under certain conditions, forms of social capital that improve the collaborative relationship between society and the state, and that embed the state more deeply in networks and types of relationships through which society can hold it to account, can be built from the side of government in the process of providing critical livelihood related services. These relationships then have the potential to become mechanisms through which people can access additional and different assets, or call on the state to defend those that they have.

\section{(iii) Social capital, rights and social control}

That state agencies and actors will respond in these constructive ways, or that efforts at popular organization will not meet with repression, violence or exclusion rather than increased government responsiveness, is of course far from certain: indeed, it is often far from even being likely. This is important, for Putnam's - and other-discussions of social capital often understate the "rawer" questions of political economy and violence. Indeed, one of the most critical "resources" that people need to access is the legalization and continuing recognition by government, military and society of rights of organization and association. Without these, struggles for access are quite likely to be unsuccessful and, indeed, repressed.

How such laws and mechanisms of enforcement might be created, and then sustained, is well beyond the scope of this paper. Still, the social capital discussion draws attention to some of the issues at stake, suggesting that the extent to which such rights will be respected and protected will depend greatly on how the state and its various institutions are embedded in society (cf. Evans, 1995), as well as how far networks within a "global civil society" are able to monitor and so influence the behavior of particular states and their agencies (cf. Hyden, 1997). The implication is that the more embedded these institutions are in networks linking them to pro-human rights and pro-poor actors in society, and the more subject they are to global scrutiny by actors with similar concerns, the less likely they are to be repressive, and the more likely they are to be constructive. This then makes it important for such pro-poor and human rights groups in society to develop - somehow - the types of relationships that can embed and monitor the state. Importantly, this will be a geographical process: thus, even if national institutions are in some sense embedded in this way, their more local arms may not be, and so may still repress, or simply not be responsive to popular pressures (Fox, 
1990). While a range of other factors, such as bureaucratic and professional culture and values (cf. Evans, 1995) also influence how the state's apparatus responds to pressure and social organization, the building of local, national and global networks that embed the state is important in creating conditions that continue to allow for processes of social organization among the popular sectors.

\section{CONCLUSION}

Though useful, because hard-headed, the discussion of campesino viability in the Andes makes three errors I wish to emphasize here. First, it tends to conflate agrarian with rural livelihoods, thus deflecting attention from the myriad transitions that have occurred in the ways through which people make a living, and the diverse assets they draw upon in the process. Second, it implies (even if this is not the intent) that rural people assess livelihood options (and thus their poverty status) according to income criteria, whereas the evidence suggests that other criteria are equally meaningful to rural people, in particular the maintenance of cultural and social practices that accompany rural residence. ${ }^{29}$ Third, it implies (again even if this is not the intent) a sort of impermeable barrier between los viables, and los no-viables - yet much of the work on access to resources, and in particular on social capital, suggests that this barrier is both permeable and movable. Just as Evans (1995) argued that forms of state-business interaction can create industrial viability in East Asia, so too certain forms of state-civil society-market-campesino interaction can create rural viability.

The framework suggested here derives from these critical reflections on the viability debate. Our analyses of rural livelihoods need to account for them in terms of: people's access to five types of capital asset; the ways in which people combine and transform those assets in the building of livelihoods that as far as possible meet their material and their experiential needs; the ways in which they are able to expand their asset bases through engaging with other actors through relationships governed by the logics of the state, market and civil society; and the ways in which they are able to deploy and enhance their capabilities both to make living more meaningful, but also more importantly to change the dominant rules and relationships governing the ways in which resources are controlled, distributed and transformed into income streams.

Within this broader framework, particular attention has been placed on one of the five assets identified as constitutive of livelihood strategies: social capital. This is for several reasons. First, to the extent that access to resources and other actors is the most critical asset that rural people need in order to build sustainable livelihoods, then people's endowments of social capital are vital to their wellbeing. Social capital inheres in the types of relationship that allow access, and is thus a critical precursor to access being possible. Second, of these different capital assets, social capital is probably the least tangible and so the one that is least understood. The paper therefore paid some attention to elaborating possible elements of its role in livelihoods and poverty alleviation. While the mechanisms for building and protecting human, produced and natural capital are clearer, the processes through which social capital is constructed are little understood, though more is certainly known about how it is destroyed. How social capital can be constructed so as to enhance the quality and sustainability of livelihoods thus merits much more attention. That, though, is another paper.

\section{NOTES}

1. It ought be noted, though, that the "environmental entitlements" framework of Leach, Mearns and Scoones. (1998) is designed for analyzing community based sustainable development programs, rather than livelihoods.

2. This "shift," however, may be more apparent than real. Pollard (1997) argues that in Europe livelihoods in marginal areas were always diversified.
3. "Assets" are thus resources that have been accessed, though in practice the paper uses the terms "asset" and "resource" interchangeably. It does not, though, use "resource" only to refer to natural resources.

4. By "hermeneutic," I am referring to those approaches which emphasize that, for any advance of knowledge, and indeed for any act of society building, it is important to understand the meanings ascribed and conveyed by different people. 
5. Leach, Mearns and Scoones (1998, p. 93) appear to touch on this observation, but do not develop it.

6. Hence the title of the paper- "Capitals and Capabilities."

7. The terms peasant and campesino are used interchangeably in the text.

8. The terms in Spanish are viables and no-viables.

9. It is also recognized that a number of the units currently deemed viable may ultimately not be, as they may never become sufficiently competitive units to survive the progressive integration of Chile into free trade areas such as Mercosur and Nafta (Kay, 1997) — an important point, because it shows that viability is a shifting state, depending on market access and relationships.

10. The FAO 1998 Rural Development Strategy Document notes the increasing importance of international migration in the functioning of rural economies and livelihoods (FAO, 1998, para 13).

11. Similar, though less dramatic examples of rural accumulation based on peri-urban trade are apparent in rural communities near the town of Llallagua, Potosí.

12. This may take the form of losing land (as in Durham's, 1995 cycles of accumulation and poverty) or financial capital and soil quality (as in Bernstein's, 1979 simple reproduction squeeze).

13. Indeed by capturing the notion of both viability and meaningfulness, the hope is that the framework will allow us to address both narrower income/expenditure and wider dignity/security based notions of poverty.

14. Serageldin and Steer (1994) in fact speak of "human made capital," though this is later termed "produced capital" in World Bank (1996) - a document heavily influenced by Steer.

15. Following the early Bank experiences with social funds, the 1990 WDR also argued that these strategies should be accompanied by safety net type funds to "catch" those adversely affected by policies fostering growth in produced capital.

16. Clearly the UNCED proceedings in Rio in 1992 gave more political weight to this idea.

17. They speak of: "weak" sustainability: to maintain total capital stock intact without regard to its compo- sition; "sensible" sustainability: maintaining total stock intact, and avoiding depletion of any particular capital stock beyond critical levels, which-since we do not know what these critical levels are-should be defined conservatively and monitored very carefully; "strong" sustainability: maintaining each component of capital intact-meaning that if natural capital is destroyed in one place, it should be replaced by cultivated natural capital in other places (e.g., as in carbon sequestration initiatives); and "absurdly strong" sustainability: in which no capital stock can be depleted at all, meaning no non-renewable resources could be used (Serageldin and Steer, 1994, pp. 31-32).

18. Indeed, some financial services NGOs such as IFOCC in Peru have experimented with this service as a less orthodox complement to the more common services they provide, such as credit and savings.

19. I am thinking of the program Yuyay Jap'ina in Potosí, Bolivia.

20. Of course, such weakening of networks may allow people greater freedom from having to redistribute their income back to members of these networks (Woolcock, 1998).

21. The authors themselves would generally have a wider notion of the nature of poverty, but it is this dimension that comes through in these frameworks.

22. Indeed, more recent participatory poverty assessments have tried to combine these different approaches and concerns, and interestingly have been vehicles for pursuing the role of social capital in household livelihood strategies (Moser, 1998).

23. This point is important, because indicators of poverty alleviation are not the same as those of sustainability, and while, say, the former may improve, this may be at the expense of an unsustainable draw down on particular capital assets.

24. Simon Batterbury (personal communication) makes a similar observation for the case of West Africa.

25. For instance market exchange, political patronage, state building, sustaining collective action for particular identity groups etc.

26. What in Sen's language would be termed turning endowments into entitlements (Sen, 1981)

27. Exercises such as the World Values Survey aim to measure "trust" and such data have been used to assess 
the links between social capital and economic growth (Knack and Keefer, 1997); but there are many difficulties with these measures.

28. It is important in this regard to note that Knack and Keefer's work originates from IRIS, the research center of the late Mancur Olson who disagreed profoundly with Putnam, instead arguing that organizations put a break on economic growth by creating constituencies that obtain rents and subsidies from the state, thus impeding the free functioning of markets.

29. Elsewhere I have argued that critical research on rural change and the peasantry ought pay more attention to income than it does. This is not to contradict the present assertion: rather the call is for understandings that, in their critique and in their proposals, pay as much attention to the material as to the hermeneutic of poverty and livelihoods.

\section{REFERENCES}

Africa (1989) Special issue on Access to Resources in Africa. Africa 59(1).

Barbier, E. (1994) Natural capital and the economics of environment and development. In Investing in Natural Capital: The Ecological Economics Approach to Sustainability, ed. A. Jansson, M. Hammer, C. Folke and R. Costanza, pp. 291-322. Island Press, Washington, DC.

Baulch, R. (1996) Neglected trade-offs in poverty measurement. IDS Bulletin 27, 36-43.

Bebbington, A. (1997) Social capital and rural intensification: Local organizations and islands of sustainability in the rural Andes. Geographical Journal 163(2), 189-197.

Bebbington, A. (1996) Organizations and intensifications: Small farmer federations, rural livelihoods and agricultural technology in the Andes and Amazonia. World Development 24(7), 1161-1178.

Bebbington, A. (1993) Sustainable livelihood development in the Andes? Local institutions and regional resource use in Ecuador. Development Policy Review 11(1), 5-30.

Bebbington, A., Kopp, A. and Rubinoff, D. (1997) From chaos to strength? Social capital, rural peoples' organisations and sustainable rural development. Paper prepared for workshop on Institutional Pluralism for Sustainable Forestry and Rural Development, Food and Agricultural Organization, Rome, December 9-12.

Bebbington, A. J. and Perreault, T. (1999) Social capital, development and access to resources in highland Ecuador. Economic Geography, October.

Bebbington, D. (1999) Turning social capital into financial capital: Women's village banking in Ayacucho and Norte Potosí. Paper prepared for Andean Studies Group seminar. Stanford University, CA, May 9.

Berdegué, J. (1990) NGOs and Farmers Organizations in Research and Extension in Chile. Agricultural Administration (Research and Extension) Network Paper, Overseas Development Institute, London.

Berdegué, J et al. (1998) Evaluación del Programa de Transferencia de Tecnología del Instituto de Desarrollo Agropecuario. Mimeo, RIMISP. Santiago, Chile.

Bernstein, H. (1979) African peasantries: A theoretical framework. Journal of Peasant Studies 6(4), 420-444.
Berry, S. (1989) Social institutions and access to resources. Africa 59(1), 41-55.

Blaikie, P. (1989) Environment and access to resources in Africa. Africa 59(1), 18-40.

Blaikie, P. (1985) The Political Economy of Soil Erosion in Developing Countries. Longmans, Harlow, $\mathrm{UK}$.

Bromley, R. (1979) The Urban Informal Sector. Pergamon Press, Oxford.

Brush, S. and Turner, B. L. (1987) The nature of farming systems and views of their change. pp. 11-48 in B. L. Turner and S. Brush (eds.) 1987.

Bryant, R. (1992) Political ecology. An emerging research agenda in Third World Studies. Political Geography 11(1), 12-36.

Carney, D. ed. (1998) Sustainable Rural Livelihooods. What Contribution Can We Make? Department for International Development, London.

Chambers, R. (1987) Sustainable Livelihoods, Environment and Development. Putting Poor Rural People First. Discussion Paper 240, Institute of Development Studies, Brighton.

Chambers, R. and Conway, G. (1992) Sustainable Rural Livelihoods: Practical Concepts for the 21st Century. IDS Discussion Paper 296, Institute of Development Studies, Brighton.

de Janvry, A. (1981) Land Reform and the Agrarian Question in Latin America. Johns Hopkins University Press, Baltimore.

Deere, C. D. and de Janvry, A. (1979) A conceptual framework for the empirical analysis of peasants. American Journal of Agricultural Economics 61, 602-611.

Durham, W. (1995) Political ecology and environmental destruction in Latin America. In The Social Causes of Tropical Deforestation in Latin America, eds. M. Painter and W. Durham. University of Michigan Press, Ann Arbor.

Durston, J. (1998) Building social capital in rural communities (where it does not exist). Paper prepared for the Latin American Studies Association annual meetings, Chicago, September 24-26.

Ellis, F. (1998) Survey article: Household strategies and rural livelihood diversification. The Journal of Development Studies 35(1), 1-38.

Enriquez, L. (1998) Structural adjustment and the Nicaraguan peasantry: Its varying impact and farm- 
ers' reactions to it. Paper presented at the Latin American Studies Association annual meetings, Chicago, September 24-26.

Evans, P. (1995) Embedded Autonomy. States and Industrial Transformation. Princeton University Press, Princeton, NJ.

Evans, P., ed. (1996) State-Society Synergy: Government and Social Capital in Development. Institute for International Studies, Berkeley, CA.

FAO (1998) Rural Development Strategy as the Focus Towards the Reduction of Extreme Poverty in the Region. Paper prepared for twenty-fifth FAO regional conference for Latin America and the Caribbean, Nassau, Bahamas, June 16-20.

Figueroa, A. (1990) La via campesina en América Latina. Mimeo.

Fox, J., ed. (1990) The Challenge of Rural Democratisation: Perspectives from Latin America and the Philippines. Frank Cass, London.

Fox, J. (1996) How does civil society thicken? The political construction of social capital in Mexico. World Development 24(6), 1089-1103.

Gellner, B. J. (1982) Colta entrepreneurship in Ecuador: A study of highland indian peddlers and the use of socio-cultural resources. Ph.D. dissertation, University of Wisconsin at Madison.

Giddens, A. (1979) Contemporary Problems in Social Theory: Action, Structure and Contradiction in Social Analysis. Macmillan, London.

Grootaert, C. (1997) Social capital, the missing link? Social Development Department, World Bank, Washington, DC.

Grootaert, C., Kanbur, R. and Oh, G. T. (1997) The dynamics of welfare gains and losses: An African case study. Journal of Development Studies 33(5), 635-657.

Gwynne, R., ed. (1997) Agrarian change and the democratic transition in Chile. Bulletin for Latin American Research 16(1).

Habermas, J. (1971) Knowledge and Human Interests. Beacon Press, Boston.

Harriss, J. and De Renzio, P. (1997) "Missing link" or analytically missing?: The concept of social capital: An introductory bibliographic essay. Journal of International Development 9(7), 919-937.

Hindess, B. and Hirst, P. (1975) Precapitalist Modes of Production. Routledge and Kegan Paul, London.

Hinojosa, L. (1998) Personal Communication. Cusco, Peru.

Hyden, G. (1997) Civil society, social capital and development: Dissection of a complex discourse. Studies in Comparative International Development 32 (1), 3-30.

IDB (1996) Bolivia: desarrollo diferente para un pais de cambios. Salir del circulo vicioso de la riqueza empobrecedora. Informe final de la Misión Piloto sobre Reforma Socio-Económica en Bolivia. La Paz Banco InterAmericano del Desarrollo.

Jokisch, B. (1998) Ecuadorian emigration and agricultural change: The persistence of small-holder agri- culture in Lower Caňar, Ecuador. Paper prepared for 1998 meeting of the Latin American Studies Association, September 24-26, Chicago.

Katz, E. (forthcoming) Social capital and natural capital: A comparative analysis of land tenure and natural resource management in Guatemala. Land Economics.

Kay, C. (1997) Globalization, peasant agriculture and reconversión. Bulletin for Latin American Research 16(1), 11-24.

Kay, C. (1995) Rural development and agrarian issues in contemporary Latin America. In Structural Adjustment and the Agricultural Sector in Latin America and the Caribbean, ed. J. Weeks, pp. 9-44. St. Martin's, London.

Kleymeyer, C., ed. (1993) Cultural Expression and Grassroots Development: cases from Latin America and the Caribbean. Lynne Reinner, Boulder, Co.

Knack, S. and Keefer, P. (1997) Does social capital have an economic payoff? A country investigation. IRIS Working Paper 197, University of Maryland at College Park, College Park.

Korovkin, T. (1992) Peasants, grapes and corporations The growth of contract farming in a Chilean community. Journal of Peasant Studies 19(2), 228254.

Korovkin, T. (1997) Taming capitalism: The evolution of the indigenous peasant economy in Northern Ecuador. Latin American Research Review 32(3), 89-110.

Lam, W. (1996) Institutional design of public agencies and co-production: A study of irrigation associations in Taiwan. In State-Society Synergy: Government and Social Capital, ed. Peter Evans, pp. 11-47. Institute of International Studies, Berkeley, CA.

Llambi, L. (1989) Emergence of capitalized family farms in Latin America. Comparative Studies in Society and History 31(4), 745-774.

Leach, M., Mearns, R. and Scoones, I. (1999) Environmental entitlement: Dynamics and institutions in community-based natural resource management. World Development 27(2), 225-247.

Leach, M., Mearns, R. and Scoones, I. (1998) Challenges to community based sustainable development: dynamics, entitlements, institutions. IDS Bulletin 28(4), 4-14.

Lehmann, A. D. (1986) Two paths of agrarian capitalism, or a critique of Chayanovian Marxism. Comparative Studies in Society and History 28(4), 601-627.

López, R. (1995) Determinants of Rural Poverty: A Quantitative Analysis for Chile. Technical Department, Rural Poverty and Natural Resources, Latin America, World Bank, Washington, DC.

Martinez, L. (1994) Los Campesinos Artesanos en la Sierra Central. El Caso de Tungurahua. Centro Andino de Acción Popular, Quito.

McCay, B. and Jentoft, S. (1998) Market or community failure? Critical perspectives on common property research. Human Organization 57(1), 21-29. 
Morris, M. (1998) Social Capital and Poverty in India. IDS Working Paper 61, Institute for Development Studies, Brighton, UK.

Moser, C. (1998) The asset vulnerability framework: Reassessing urban poverty reduction strategies. World Development 26(1), 1-19.

Narayan D. and Pritchett, L. (forthcoming) Cents and Sociability: Household Income and Social Capital in Rural Tanzania. Economic Development and Cultural Change.

Netting, R. McC. (1993) Smallholders, Householders: Farm Families and the Ecology of Intensive, Sustainable Agriculture. Stanford University Press, Stanford, CA.

Netting, R. McC. (1981) Balancing on an Alp. Ecological Change and Continuity in a Swiss Mountain Community. Cambridge University Press, Cambridge, UK.

North, L. and Cameron, J. (1998) Grassroots based rural development strategies: Ecuador in comparative perspective. Paper prepared for the Latin American Studies Association annual meetings, Chicago, September 24-26.

Ostrom, E. (1996) Crossing the Great Divide: Coproduction, synergy and development. World Development 24(6), 1073-1088.

Ostrom, E. (1994) Neither State nor Market: Governance of Common Pool Resources in the 21st Century. Lecture Series, June 2. IFPRI, Washington, DC.

Perreault, T., Bebbington A. and Carroll T. (1998) Indigenous irrigation organizations and the formation of social capital in Northern Highland Ecuador. Conference of Latin American Geographers Yearbook 24, 1-16.

Pollard, S. (1997) Marginal Europe. Oxford University Press, Oxford.

Preston, D. (1998) Post-peasant capitalist graziers: the 21 st century in southern Bolivia. Mountain Research and Development 18(2), 151-158.

Preston, D. (1997) Migration. In Latin American Development: Geographical Perspectives, ed. D. Preston. Longmans, Harlow, UK.

Putnam, R. (1993) Making Democracy Work: Civic Traditions in Modern Italy. Princeton University Press, Princeton, NJ.

Ramón, G. (1988) Indios, Crisis y Proyecto Alternativo. Centro Andino de Acción Popular, Quito.

Rasnake, R. (1988) Domination and Cultural Resistance. Authority and Power Among an Andean People. Duke University Press, Durham, NC.

Ribot, J. (1998) Theorizing access: forest profits along Senegal's charcoal commodity chain. Development and Change 29(2), 307-342.

Salomon, F. (1981) The weavers of Otavalo. In Cultural Transformations and Ethnicity in Modern Ecuador. ed. N. Whitten, pp. 420-449. University of Illinois Press, Urbana.

Scoones, I. (1998) Sustainable Rural Livelihoods: A Framework for Analysis. Working Paper 72, Institute for Development Studies, Brighton, UK.
Scoones, I. and Thompson, J., eds. (1994) Beyond Farmer First: Rural People's Knowledge, Agricultural Research and Extension Practice. IT Publications. London.

Sen, A. (1981) Poverty and Famines: An Essay on Entitlement and Deprivation. Oxford University Press, Oxford.

Sen, A. (1997) Editorial: Human capital and human capability. World Development 25(12), 1959-1961.

Serageldin, I. and Steer A. (1994) Epilogue: Expanding the capital stock. In Making Development Sustainable: From Concepts to Action, ed. I. Serageldin and A. Steer. Environmentally Sustainable Development Occasional Paper Series No. 2, World Bank, Washington, DC.

Sinergia (1998) Grassroots Organizations and Local Development in Bolivia. Wold Bank, Washington, DC.

Sotomayor, O. (1994) Políticas de Modernización y Reconversión de la Pequeña Agricultura Tradicional Chilena. ODEPA and IICA. Santiago.

Tendler, J. (1997) Good Government in the Tropics. Johns Hopkins University Press, Baltimore.

Tendler, J. and Freedheim, S. (1994) Trust in a rent seeking world: Health and government transformed in North-East Brazil. World Development 22 (12), 1771-1991.

Tolen, R. (1995) Wool and Synthetics, Countryside and City: Dress, Race and History in Chimborazo, Highland Ecuador. Ph.D. dissertation, Department of Anthropology, University of Chicago, Chicago.

Turner, B. L. and Brush, S. (1987) Comparative Farming Systems. The Guilford Press, New York.

VMPPFM-Banco Mundial (1998) Estudio de Productividad Rural y Manejo de Recursos Naturales: Informe Principal. Vice Ministerio de Participación Popular y Fortalecimiento Municipal, La Paz, Bolivia.

van Niekerk, N. (1994) El Desarrollo Rural en Los Andes. Un Estudio sobre los programas de desarrollo de Organizaciones no Gubernamentales. Leiden Development Studies No. 13, University of Leiden, Leiden, Netherlands.

van Niekerk, N. (1997) La cooperación internacional y las políticas públicas: el caso de las zonas andinas de altura de Bolivia. Ponȩncia presentada al Seminario Internacional sobre Estrategías Campesinas, 3-4 abril de 1997, Sucre, Bolivia.

Weeks, J., ed. (1995) Structural Adjustment and the Agricultural Sector in Latin America and the Caribbean. St. Martin's Press, London.

Woolcock, M. (1998) Social capital and economic development: Toward a theoretical synthesis and policy framework. Theory and Society 27(2), 151208.

World Bank (1990) World Development Report 1990. Oxford University Press, New York.

World Bank (1996) Social Capital. Unpublished manuscript of the Satellite Group on social capital. 
World Bank (1997) Expanding the Measure of Wealth: Indicators of Environmentally Sustainable Development. Environmentally Sustainable Development Studies and Monographs Series, No. 17, World Bank, Washington, DC.

Yapa, L. (1998) The poverty discourse and the poor in Sri Lanka. Transactions of the Institute of British Geographers NS 23, 95-115.
Zoomers, A. (1998) Estrategías Campesinas en el Surandino de Bolivia: Intervenciones y desarrollo rural en el norte de Chuquisaca and Potosí. CEDLA/CID/PLURAL, La Paz. 